\title{
Posterior Tongue Mucoepidermoid
} \section{Carcinoma}

National Cancer Institute

\section{Source}

National Cancer Institute. Posterior Tongue Mucoepidermoid Carcinoma. NCI

Thesaurus. Code C5990.

A mucoepidermoid carcinoma arising from the minor salivary glands in the base of the tongue. 